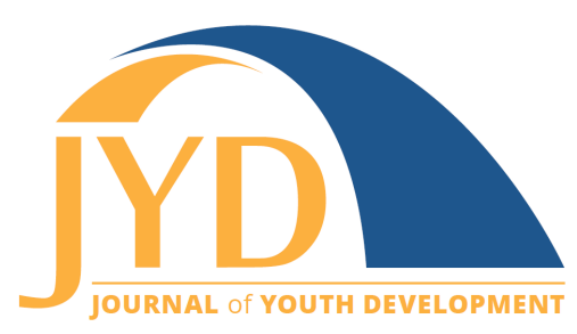

http://jyd.pitt.edu/ | Vol. 16 Issue 1 DOI 10.5195/jyd.2021.970 | ISSN 2325-4017 (online)

\title{
Learning, Idea Sharing, and Transfer From a State 4-H Camp Counselor Workshop
}

\author{
Hannah K. Epley \\ The Ohio State University \\ epley.24@osu.edu \\ Christy D. Clary \\ The Ohio State University \\ clary.42@osu.edu

\section{Erin S. Dailey} \\ The Ohio State University \\ dailey.108@osu.edu
}

\begin{abstract}
Making eXtreme Counselors is a winter statewide camp counselor training workshop to prepare for the camp season. This training brings teens throughout Ohio together to help prepare them to serve as camp counselors in their own counties. Participants engage in competency-focused breakout sessions led by a variety of 4-H professionals, keynote presentations, and peer-to-peer sharing and interactions. To evaluate the workshop's impact on the summer camping program, data from both teen participants and the 4-H professionals who worked with them were collected following the program for 3 years. Results indicated high ratings on gaining or enhancing skills related to leadership, teamwork, and the campingrelated competencies covered in the workshop. In addition, the results indicated that participants shared ideas learned at the workshop with others and transferred their learning from the training to their performance as a camp counselor. Youth development professionals can adopt similar training strategies to enhance participants'skills.
\end{abstract}

Key words: camp counselor, competency, skill development, teens, training

\section{Introduction}

A positive youth development approach focuses on qualities and opportunities youths need to become successful. Essential elements, which are program features that support social,

(cc) EY New articles in this journal are licensed under a Creative Commons Attribution 4.0 License. This journal is published by the University Library System, University of Pittsburgh and is cosponsored by the University of Pittsburgh Press. The Journal of Youth Development is the official peer-reviewed publication of the National Association of Extension 4-H Youth Development Professionals and the National AfterSchool Association. 


\section{State 4-H Camp Counselor Workshop}

physical, and emotional well-being, are used as a framework for the 4-H program (National 4-H Headquarters, 2011). The camp experience represents a distinct and unique youth development setting (Garst et al., 2011; Garst et al., 2016). Garst and Johnson (2005) note that camping is not just the actual time spent at camp; it also includes the affective, cognitive, behavioral, physical, social, and spiritual outcomes of camp participation. Nationally, camping is an important 4-H delivery model that provides many of the essential elements (Garst \& Johnson, 2005).

In many states, including Ohio, teens often serve as camp counselors in 4- $\mathrm{H}$ camping programs. Specifically, in Ohio this role consists of selection, training, preparation, and participation in the actual camp program (Ferrari \& Arnett, 2011; Ferrari \& McNeely, 2007). Many teens continue their role by contributing to the camp evaluation. It is the responsibility of the adults overseeing camp programs to ensure that camp counselors are prepared to serve in these roles (Baldwin et al., n.d.). In the Ohio 4-H program, 4-H professionals are responsible for selecting and providing the necessary training for teens who serve as camp counselors at their respective county-based camps (Ferrari \& McNeely, 2007; Ferrari \& Risch, 2013), which take place at 15 different camp facilities. The timing of the selection of teen camp counselors varies from county to county and typically occurs between October and February. The 4-H professionals, who are responsible for running the local 4- to 5-day camps, must balance the needs of two audiences: the young people who attend as campers and the teen camp counselors who are integral to carrying out the camp program (Ferrari \& McNeely, 2007). To that end, they spend a considerable amount of their time working with camp counselors in the pre-camp planning phase.

To hold a successful camp, camp counselors must be prepared to plan and implement it in alignment with the camp goals. To foster this preparation, the Ohio 4-H program requires camp counselors to receive between 12 and 24 hours of training. County 4-H professionals are responsible for conducting this training, which typically begins in January and occurs routinely until the onset of summer camp. As with any employment or volunteer opportunity, training needs to be effective in providing the necessary knowledge, skills, and behaviors to ensure success. Therefore, program leaders intentionally design training with a focus on these desired outcomes (Galloway et al., 2013; Gillard \& Roark, 2017).

Camp counselors gain skills desirable in the workforce (e.g., organization, communication, public speaking, teamwork, and working with children), have an opportunity to practice them 


\section{State 4-H Camp Counselor Workshop}

during camp, and then transfer them to other settings (Bird \& Subramaniam, 2018; Digby \& Ferrari, 2007). To create an environment focusing on workforce development, professionals must identify experiences that will aid young people in gaining applied skills (Duerden et al., 2014).

Ohio 4-H's Making eXtreme Counselors (MXC) workshop is one example of creating intentional opportunities that focus on gaining specific knowledge, skills, and abilities. Conducted since 2009, the ultimate objective is that camp counselors put what they learned at the workshop into practice in the camp setting. To evaluate whether these goals were realized, we collected data for 3 years to assess (a) if skills and knowledge were gained from the MXC workshop; (b) whether or not counselors shared ideas from the workshop in their county-level camping program with peer camp counselors, adult camp staff, and/or 4-H professionals who serve as camp directors; and (c) if those skills and knowledge transferred to their role as a camp counselor in the summer camping program.

\section{Review of Literature}

\section{Competencies}

Building competencies is a main goal of education. Competencies are the knowledge, skills, abilities, and other characteristics associated with high performance (McClelland, 1973). A competency model describes what individuals need to know to perform their duties; it may contain behavior, knowledge, and motivational dimensions (Byham \& Moyer, 2005). Organizations have recognized the benefits of developing a competency model, including better processes for recruiting and selecting employees, designing training and development opportunities, and conducting performance evaluations (Campion et al., 2011). Ohio 4-H camp counselor training focuses on the 15 competencies identified by Epley (2014); Table 1 provides the competencies and their description.

Epley et al., (2017) recommend designing camp counselor training in areas that enhance camp counselor competencies. By providing this intentional training, teens serving as camp counselors can develop their skills and abilities while fulfilling their camp counseling responsibilities. Those camp counselors who demonstrate high levels of perceived competencies may fulfill and perform their responsibilities to a higher degree (Wahl-Alexander et al., 2018), which lends support to the idea of focusing on camp counselor competency-based training. 
Table 1. Ohio 4-H Camp Counselor Competency Model

\begin{tabular}{|c|c|}
\hline Competency & Description \\
\hline $\begin{array}{l}\text { Child and adolescent } \\
\text { development } \\
\text { knowledge }\end{array}$ & $\begin{array}{l}\text { Understands youths and their needs, along with the ages and stages of youth } \\
\text { development; has an understanding of behavior management techniques and guidelines; } \\
\text { puts knowledge into practice. }\end{array}$ \\
\hline Communication & $\begin{array}{l}\text { Communicates effectively with others using a variety of methods, including active listening, } \\
\text { observation, direct conversation, and public speaking, in both individual and group } \\
\text { settings; has conflict mediation skills. }\end{array}$ \\
\hline Cultural awareness & $\begin{array}{l}\text { Understands and accepts differences in others; appreciates different talents; relates to and } \\
\text { connects with diverse groups of people, including those in various cultures, those with } \\
\text { specials [sic] needs, and those having varied backgrounds. }\end{array}$ \\
\hline $\begin{array}{l}\text { Health, wellness, } \\
\text { and risk } \\
\text { management }\end{array}$ & $\begin{array}{l}\text { Is watchful and knows what to look for regarding potential health and safety concerns and } \\
\text { how to deal with and react to situations; has knowledge of emergency procedures and the } \\
\text { protocols to implement should an emergency arise; has knowledge of how to manage his } \\
\text { or her own stress and support the physical and emotional well-being of the camp } \\
\text { community and has basic first aid skills. }\end{array}$ \\
\hline $\begin{array}{l}\text { Personal } \\
\text { commitment }\end{array}$ & $\begin{array}{l}\text { Is committed to the philosophy and goals of camp and is devoted to the position of camp } \\
\text { counselor; has a sense of selflessness; takes ownership of and has buy-in regarding the } \\
\text { influence and impact he or she has on the program. }\end{array}$ \\
\hline $\begin{array}{l}\text { Professional } \\
\text { development }\end{array}$ & $\begin{array}{l}\text { Has a willingness to be coached and challenged; accepts feedback and guidance from } \\
\text { adults and peers; seeks opportunities to continually improve knowledge, skills, and } \\
\text { capabilities; develops job-seeking skills (including those associated with completing an } \\
\text { application, providing references, and undergoing screening and selection processes). }\end{array}$ \\
\hline Professionalism & $\begin{array}{l}\text { Demonstrates behaviors that reflect high levels of maturity, responsibility, flexibility and } \\
\text { adaptability, honesty, and trustworthiness; has an appropriate sense of humor; has a } \\
\text { positive attitude; energetically shares knowledge; avoids a sense of entitlement; is } \\
\text { engaged and respects people and things; demonstrates customer service and maintains } \\
\text { confidentiality. }\end{array}$ \\
\hline Program planning & $\begin{array}{l}\text { Designs, creates, and plans appropriate programs and workshops to engage all } \\
\text { participants; is prepared to implement these programs. }\end{array}$ \\
\hline Role modeling & $\begin{array}{l}\text { Is someone who others aspire to be like; models, demonstrates, and teaches positive } \\
\text { values; has fun in a positive and responsible way. }\end{array}$ \\
\hline Self-direction & $\begin{array}{l}\text { Takes initiative and does things from start to finish with all the details and without being } \\
\text { asked; works unsupervised; admits and recognizes mistakes he or she has made. }\end{array}$ \\
\hline
\end{tabular}

Adapted from "Making eXtreme Counselors: A State 4-H Camp Counselor Workshop," by H. K. Epley, J. Williams, K. Feldhues, and L. Hall, 2018, Journal of Extension, 56(6), iw5. Copyright 2018 by Extension Journal, Inc. 


\section{State 4-H Camp Counselor Workshop}

\section{Camp and the Connection to Workforce Skills}

Serving as a camp counselor is an opportunity for teens to gain valuable skills in the areas of leadership, teamwork, and communication (Bird \& Subramaniam, 2018; Digby \& Ferrari, 2007; Ferrari \& McNeely, 2007; Ferrari \& Risch, 2013; Garst et al., 2011; Garst \& Johnson, 2005; Nicholson \& Klem, n.d.). Not only is it desirable for camp counselors to gain these skills so they can be successful in their role, but employers desire these same specific skills and abilities (Cochran \& Ferrari, 2009). Ferrari et al. (2008) discussed the importance of being able to provide youth with opportunities to develop basic skills and competencies necessary to succeed in the workplace. The camp experience is one place where individuals gain skills applicable to future workplace settings (Duerden et al., 2014). The counseling experience has also been reported to catalyze personal change by developing an improved ability to work with children and by being exposed to new people, new activities, and new experiences (Leff et al., 2015). Camp counselors also have reported having a stronger desire to stay in school and feeling more prepared for college as a result of their counseling experience (Nicholson \& Klem, n.d.).

\section{Transfer of Learning}

Central to accomplishing the workshop's goals is the concept of transfer of learning. Once learners acquire knowledge, they need to transfer it, that is, to use it and apply it in a realworld setting. Transfer of learning is the goal of camp counselor training because camp counselors must not only acquire knowledge, but they must also plan and carry out the camp (i.e., the real-world setting). Transfer of learning would indicate that meaningful learning had occurred (Mayer, 2002).

Transfer of learning is complex and involves higher-order thinking skills (Schunk, 2012). On the one hand, assessment of transfer of learning is difficult because it requires more than simply recalling or recognizing factual knowledge. However, on the other hand, camp counselors essentially create a product, a performance (which focuses on the process), or some combination of product and performance (e.g., the plan for a campfire program and actually teaching others to sing camp songs as part of the program). Therefore, an authentic assessment of transfer of learning could be made by someone viewing the camp counselors' actual implementation of camp program components. Such observation aligns with recommended methods for assessing competencies (Klieme et al., 2008). 


\section{State 4-H Camp Counselor Workshop}

\section{Program Description}

The Ohio 4-H program focuses on specific competencies for training camp counselors developed by Epley (2014). The extent of this training may differ from county to county based on the needs of the camping facility and local needs of the camping program. Most of the training for over 2,000 teen camp counselors takes place at the county level, but there are additional optional opportunities for camp counselors to attend so they can expand their horizons beyond what is taught at the county level. One of these is the Making eXtreme Counselor workshop, which annually hosts approximately 120 camp counselors.

Making eXtreme Counselors (MXC) is an annual statewide camp counselor training workshop that supplements the county and site-specific training opportunities that take place throughout the year (Epley et al., 2018). A committee of 4-H professionals plans this 2-day, 1-night winter weekend training. To teach important competencies, it is designed to mirror the elements of a camp experience in a setting that allows for peer-to-peer sharing and interactions.

When registering for the workshop, camp counselor participants indicate their program planning session preference. Camp counselor participants are purposefully placed into this session based on their preference, geographic location, gender, and years of experience as a camp counselor. By mixing camp counselors with varying degrees of experience together in sessions, returning camp counselors can add value by providing insight from their past experiences (Baldwin et al., n.d.). Camp counselors self-select the remaining sessions, which supports their need for autonomy. Learners improve after the training activities when they assume primary responsibility for learning decisions (e.g., choosing learning activities; Bell \& Kozlowski, 2008).

The workshop format is as follows:

- The workshop begins with an opening session led by a guest speaker, who is an expert in the field.

- Camp counselor workshop participants then attend hands-on breakout sessions that address the program planning competency. Participants learn foundational knowledge about program planning and then plan for a program that will be implemented at the workshop (e.g., evening recreation, flag ceremonies, campfire, and reflections). Program planning is a competency central to the camp counselor experience, so it is included every year.

- These planned programs are embedded at various times throughout the workshop, such as planning for the evening campfire, flag lowering ceremony, or 


\section{State 4-H Camp Counselor Workshop}

end of day reflections. Additionally, participants are encouraged to share songs, ice breakers, and other games and activities when appropriate.

- Next, there are four blocks of educational sessions, with multiple offerings in each block (seven per block for a total of 28 different offerings). These are led by the guest speaker and a variety of 4-H professionals and focus on four of the remaining 14 competencies (see Table 1; Epley, 2014; Epley et al., 2017). The competencies covered change each year until all competencies have been taught over a 3- to 4-year training cycle.

- The closing session is led by the guest speaker.

Throughout the workshop, the focus is on the experiential learning process (Kolb, 1984). There are opportunities for participants to gain a better understanding of the camping program and practice critical thinking skills. To enhance the transfer of learning from the workshop to the county camping program, participants teach and share songs, games, and activities to their peers. They are encouraged to share ideas and reflect upon how concepts can be implemented in their county camping program. By practicing certain aspects during the training and reflecting upon experiences, transferring knowledge to new contexts is maximized (Silliman et al., 2020).

At the conclusion of the workshop, all camp counselor participants complete an evaluation that includes questions regarding the quality of the sessions, guest speaker, and food. This information has been used to improve the program from year to year. They are also asked about skills they gained and whether they think those skills will assist them in their role as a camp counselor. After the MXC training, camp counselors receive additional county-level training in their respective counties, make plans for their county camp, and then implement 4-H camps during the summer. County 4-H professionals work with camp counselors and observe them during the training and implementation of the $4-\mathrm{H}$ camp.

\section{Method}

\section{Design}

We wanted to further assess the effectiveness of the MXC workshop in achieving the long-range goal of effective camp programs. Therefore, we decided to send a questionnaire following the camping season to camp counselor workshop participants and their respective 4-H professionals to assess perceptions of camp counselors' skills gained and used in their own county camping programs. By surveying more than one population on the same topic, different viewpoints of the same topic can be captured (Seale, 2010). Refer to Figure 1 for a visual representation of the timeline. 
For the study reported here we combined data from the most recent 3 years of program evaluations, because it takes several years to have training on all 15 camp counselor competencies. By including 3 years, all competencies were assessed for the study. The objectives of the study were to assess (a) if skills and knowledge were gained from the workshop; (b) whether or not they shared ideas from the workshop in their county-level camping program with peer camp counselors, adult camp staff, and/or 4-H professionals who serve as camp directors; and (c) if those skills and knowledge transferred to their role as a camp counselor in the summer camping program.

Figure 1. Program and Study Timeline

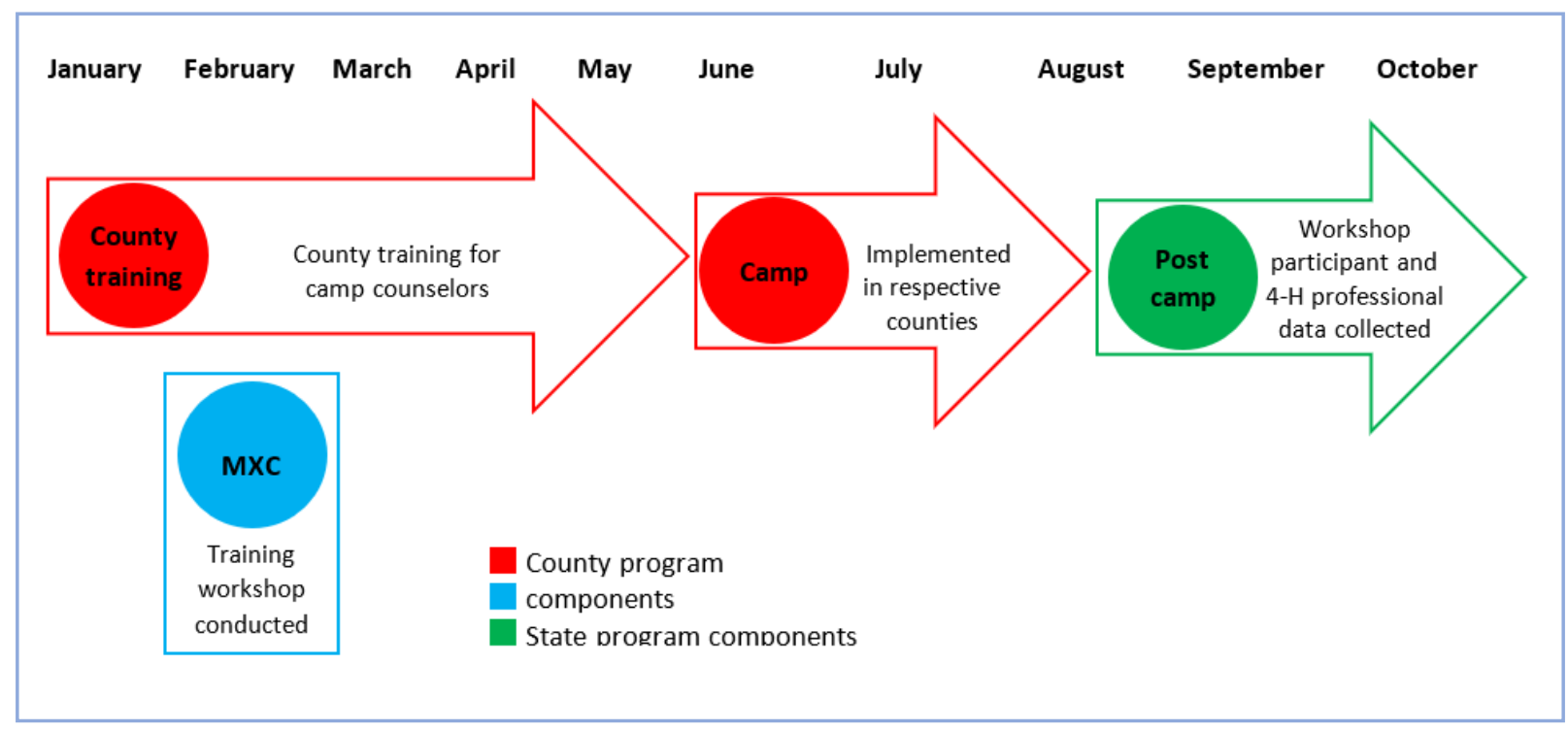

\section{Participant Characteristics}

There were two separate participant populations surveyed: camp counselor workshop participants and the 4-H professionals who worked with them. These groups were surveyed each year for 3 years. Specific demographics for each group are presented in the following sections.

\section{Camp Counselors}

All camp counselor workshop participants $(N=413)$ received the questionnaire at the conclusion of the summer camping program and the response rate was $46.9 \%(N=194)$. Because participants had the opportunity to attend the workshop for multiple years, some 


\section{State 4-H Camp Counselor Workshop}

individuals received the questionnaire more than once. Therefore, for the purposes of this study, we decided to report the results from first-year workshop participants, which eliminated duplicate responses from the same participant. The remaining data set included responses from 117 first-year workshop participants. Over half $(63.7 \%)$ of respondents were first- or secondyear camp counselors. Three quarters (76.5\%) identified as female, which is representative of the teen camp counselors throughout the state. Over the course of the 3 years, camp counselors represented 38 of Ohio's 88 counties, with a range of 15 to 24 counties in a given year. Tables 2 and 3 provide additional demographic details.

\section{Table 2. Years as a Camp Counselor}

\begin{tabular}{|c|c|c|c|c|}
\hline $\begin{array}{c}\text { Number of } \\
\text { years }\end{array}$ & $\begin{array}{c}\mathbf{2 0 1 7} \\
(\boldsymbol{N}=\mathbf{1 3})\end{array}$ & $\begin{array}{c}\mathbf{2 0 1 8} \\
(\boldsymbol{N}=\mathbf{1 7})\end{array}$ & $\begin{array}{c}\mathbf{2 0 1 9} \\
(\boldsymbol{N}=\mathbf{1 7})\end{array}$ & $\begin{array}{c}\text { TOTAL } \\
(\mathbf{N}=\mathbf{4 7})^{\mathrm{a}}\end{array}$ \\
\hline 1 & $4(30.7 \%)$ & $5(29.4 \%)$ & $5(29.4 \%)$ & $14(29.7 \%)$ \\
\hline 2 & $6(46.1 \%)$ & $6(35.2 \%)$ & $4(23.5 \%)$ & $16(34.0 \%)$ \\
\hline 3 & $2(15.3 \%)$ & $3(17.6 \%)$ & $4(23.5 \%)$ & $9(19.1 \%)$ \\
\hline 4 & $1(7.6 \%)$ & $1(5.8 \%)$ & $1(5.8 \%)$ & $3(6.3 \%)$ \\
\hline 5 & 0 & $2(11.7 \%)$ & 0 & $2(4.2 \%)$ \\
\hline 6 & 0 & 0 & $3(17.6 \%)$ & $3(6.3 \%)$ \\
\hline
\end{tabular}

a 117 individuals responded to the survey, but only 47 individuals responded to this question.

Table 3. Camp Counselors' Gender

\begin{tabular}{|c|c|c|c|c|}
\hline Gender & $\begin{array}{c}\mathbf{2 0 1 7} \\
(\mathbf{N = 2 8 )}\end{array}$ & $\begin{array}{c}\mathbf{2 0 1 8} \\
(\mathbf{N}=\mathbf{2 3})\end{array}$ & $\begin{array}{c}\mathbf{2 0 1 9} \\
(\mathbf{N}=\mathbf{3 0})\end{array}$ & $\begin{array}{c}\text { TOTAL } \\
(\mathbf{N}=\mathbf{8 1})^{\mathrm{a}}\end{array}$ \\
\hline Male & $9(32.1 \%)$ & $7(30.4 \%)$ & $3(10.0 \%)$ & $19(23.4 \%)$ \\
\hline Female & $19(67.8 \%)$ & $16(69.5 \%)$ & $27(90.0 \%)$ & $62(76.5 \%)$ \\
\hline
\end{tabular}

a117 individuals responded to the survey, but only 81 individuals responded to this question.

\section{4-H Professionals}

4-H professionals $(N=96)$ received the questionnaire when they had one or more camp counselors attend the workshop; the response rate was $81.2 \%(N=78)$. Upon review, 24 respondents completed the survey more than one year. When removing duplicates, a total of 43 unique individuals responded. Of these 43 unique respondents, there were 38 females and five males, which is representative of the 4-H professionals in the state. It is important to note these professionals were asked to assess the workshop participants from the current year. Thirty- 


\section{State 4-H Camp Counselor Workshop}

eight counties were represented over the course of 3 years. Table 4 presents this information by each year.

Table 4. 4-H Professional Demographics

\begin{tabular}{|l|c|c|c|}
\hline \multirow{2}{*}{} & \multicolumn{2}{|c|}{ Gender } & Number of counties represented \\
\cline { 2 - 4 } & Males & Females & 24 \\
\hline $2017(N=24)$ & 4 & 20 & 29 \\
\hline $2018(N=29)$ & 4 & 25 & 25 \\
\hline $2019(N=25)$ & 3 & 22 & 38 \\
\hline Total without duplicates & 5 & 38 & \\
\hline
\end{tabular}

\section{Instrument}

We developed two questionnaires, one for camp counselor workshop participants and one for the $4-\mathrm{H}$ professionals. A description of the relevant measures from each instrument follows.

\section{Camp Counselors}

The camp counselor workshop participant instrument focused on three areas: skills gained, ideas shared, and skills transferred. Questions related to skills gained from the workshop assessed the skills that were used in the camping experience (e.g., camp planning, how to handle various scenarios that occur at camp, dances, and songs) to determine the highest rated skills and how they were used in their camp counselor role. Two questions related to skills transferred from the workshop to their camp counselor role and other areas of their life (school, work, etc.). When camp counselors indicated they shared ideas with others during the camp training and planning portion of the camping program, they also indicated the type of information shared at that time. This information was requested so we could capture what the camp counselors were sharing with their peers and the adults who work with them. The questionnaire included demographic questions, including gender, number of years as a camp counselor, and geographic location (i.e., county). Table 5 provides examples of the questions and response options. 
Journal of Youth Development | http://jyd.pitt.edu/ | Vol. 16 Issue 1 DOI 10.5195/jyd.2021.970

State 4-H Camp Counselor Workshop

Table 5. Sample Questions and Response Formats for Camp Counselor Instrument

\begin{tabular}{|c|c|c|}
\hline Area measured & Question & Response options \\
\hline Skills gained & $\begin{array}{l}\text { What skills gained from MXC did you } \\
\text { utilize in your camping experience? } \\
\text { (indicate all that apply) }\end{array}$ & $\begin{array}{l}\text { - } \text { Camp planning } \\
\text { - Caring for campers } \\
\text { - } \text { Dances } \\
\text { - How to deal with difficult campers or } \\
\text { - } \text { camper behaviors } \\
\text { - } \text { occur to handle various scenarios that } \\
\text { - } \quad \text { Ideames/icebreakers } \\
\text { - } \text { activities approaches for themes or } \\
\text { - } \text { Professional development } \\
\text { - Songs } \\
\text { - Teaching methods or approaches } \\
\text { - Teamwork or cooperation } \\
\text { - Thinking and problem solving } \\
\text { - Understanding organizational and } \\
\text { camp environment } \\
\text { I did not utilize any skills gained from } \\
\text { MXC in my camping experience }\end{array}$ \\
\hline Skills gained & $\begin{array}{l}\text { Of the items indicated in the previous } \\
\text { question, what do you feel is the item } \\
\text { you utilized the MOST in your camping } \\
\text { program? (select one) }\end{array}$ & Same options as the previous question. \\
\hline Skills gained & $\begin{array}{l}\text { Do you believe you utilized skills gained } \\
\text { from the (competency name) sessions } \\
\text { (list of session titles) during your } \\
\text { camping experience? a }\end{array}$ & $\begin{array}{l}\text { - } \quad \text { Yes } \\
\text { - } \text { Maybe } \\
\text { - } \quad \text { No }\end{array}$ \\
\hline
\end{tabular}




\section{State 4-H Camp Counselor Workshop}

Table 5. (continued)

\begin{tabular}{|c|c|c|}
\hline Area measured & Question & Response options \\
\hline Transfer & $\begin{array}{l}\text { I am a better counselor because I } \\
\text { attended MXC. }\end{array}$ & $\begin{array}{ll}\text { - } & \text { Strongly disagree } \\
\text { - } & \text { Disagree } \\
\text { - } & \text { Agree } \\
\text { - } & \text { Strongly agree }\end{array}$ \\
\hline Transfer & $\begin{array}{l}\text { I gained skills at MXC that will be able to } \\
\text { be transferred to other areas of life, } \\
\text { besides camp (school, work, etc.) }\end{array}$ & $\begin{array}{ll}\text { - } & \text { Strongly disagree } \\
\text { - } & \text { Disagree } \\
\text { - } & \text { Agree } \\
\text { - } & \text { Strongly agree }\end{array}$ \\
\hline Ideas sharing & $\begin{array}{l}\text { Did you share ideas for games and } \\
\text { programs you learned at MXC with } \\
\text { others? }\end{array}$ & $\begin{array}{l}\text { - } \quad \text { Yes } \\
\text { - } \quad \text { No } \\
\text { (if yes) What ideas for games and } \\
\text { programs did you share with others? } \\
\text { (open ended) }\end{array}$ \\
\hline
\end{tabular}

a Separate questions were asked naming each competency for each session.

\section{4-H Professionals}

The 4-H professionals instrument focused on three areas: skills gained, ideas shared, and program satisfaction indicators. Because camp counselors also received county training, 4- $\mathrm{H}$ professionals were asked to relate their responses to the camp counselor participants' workshop experience and how it impacted the camp counselors' role in the camping program. We wanted to determine if perspectives of the camp counselor workshop participants aligned with those of the 4-H professionals who worked with them. We assessed skills gained from the 4-H professionals' perspective to identify the highest rated skills. We assessed if camp counselors shared ideas with others to determine if the camp counselors transferred items they learned at the workshop (e.g., songs, games, ideas for activities) to the camping program. To assist in determining if the current workshop format met their needs, we asked questions related to program satisfaction. Demographic characteristics gathered included gender and geographic location (i.e., county). Table 6 provides examples of the questions and response options. 
Table 6. Questions and Response Options for 4-H Professional Instrument

\begin{tabular}{|c|c|c|}
\hline Area measured & Question & Response options \\
\hline Skills gained & $\begin{array}{l}\text { Do you believe your counselor(s) } \\
\text { gained or improved their skills } \\
\text { (decision-making, leadership, } \\
\text { teamwork) because they attended } \\
\text { MXC? }\end{array}$ & $\begin{array}{l}\text { - No, not at all } \\
\text { - To a small extent } \\
\text { - To a moderate extent } \\
\text { - To a great extent }\end{array}$ \\
\hline Skills gained & $\begin{array}{l}\text { Select the areas you believe your } \\
\text { counselors(s) gained or improved their } \\
\text { skills related to the following } \\
\text { competencies: (select all that apply) }\end{array}$ & $\begin{array}{l}\text { - The five competencies covered that } \\
\text { year were listed, along with their } \\
\text { respective definition, for example: } \\
\text { - Communication (Communicates } \\
\text { effectively with others using a variety of } \\
\text { methods including active listening, } \\
\text { observation, direct conversation, and } \\
\text { public speaking, in both individual and } \\
\text { group settings; has conflict mediation } \\
\text { skills) } \\
\text { I do not believe they gained or } \\
\text { improved any of these skills }\end{array}$ \\
\hline Idea sharing & $\begin{array}{l}\text { Did counselors who attended MXC } \\
\text { share new activities learned at MXC } \\
\text { with others (including games, } \\
\text { programs, songs, etc.)? }\end{array}$ & $\begin{array}{l}\text { - } \quad \text { Yes } \\
\text { - } \quad \text { (if yes) What activities or ideas did they } \\
\text { share? (open ended) }\end{array}$ \\
\hline $\begin{array}{l}\text { Program } \\
\text { satisfaction } \\
\text { indicator }\end{array}$ & $\begin{array}{l}\text { What do you believe is the main benefit } \\
\text { of having MXC? (select one) }\end{array}$ & $\begin{array}{l}\text { - Counselor receiving training hours } \\
\text { counselors enhancing their skills as a } \\
\text { - Opportunity for counselors to share } \\
\text { ideas } \\
\text { - Other (please specify) }\end{array}$ \\
\hline $\begin{array}{l}\text { Program } \\
\text { satisfaction } \\
\text { indicator }\end{array}$ & $\begin{array}{l}\text { How likely are you to send counselors } \\
\text { to MXC in future years? }\end{array}$ & $\begin{array}{ll}\text { - } & \text { Not likely } \\
\text { - } & \text { Somewhat likely } \\
\text { - } & \text { Very likely }\end{array}$ \\
\hline
\end{tabular}




\section{State 4-H Camp Counselor Workshop}

\section{Data Collection and Analysis}

At the conclusion of each camping season, a link to an online questionnaire was emailed to the total population of workshop participants and their respective county $4-\mathrm{H}$ professionals. The questionnaire was administered through Qualtrics, a platform for the creation, distribution, and analysis of online surveys. Three reminder emails were sent to participants over the course of 2 weeks. The overall response rates were $46.9 \%(N=194)$ for camp counselors workshop participants and $81.2 \%(N=78)$ for $4-\mathrm{H}$ professionals. Likert-type items were analyzed with frequency distributions (Boone $\&$ Boone, 2012) and open-ended responses were reviewed, coded, and categorized.

\section{Results}

\section{Camp Counselors}

The vast majority of camp counselor workshop participants believed they were a better camp counselor due to attending the workshop (96.0\%), which allowed them to gain skills for their camp role (94.7\%). The camp counselors identified the following skills gained from the workshop as being used during camp: how to handle various scenarios that occur at camp, leadership skills, songs, games/icebreakers, and how to deal with difficult campers or behaviors. The workshop topics camp counselors used most often were communication, teamwork, and handling difficult situations arising at camp. Other items counselors reported using included making connections with individuals throughout the state and sharing ideas with individuals at the training to bring back to their own county program.

The majority of camp counselor participants indicated they gained skills from the competency sessions in the workshop. The program planning session, which is offered annually, is highly rated each year (overall percentage of yes response was $81.9 \%$ with $N=105$ ). Three sessions were particularly useful: teaching and facilitating, role model, and understanding organizational and camp environment. Table 7 presents these findings.

Nearly all camp counselors (96.0\%) indicated that they shared ideas for games and programs learned at the workshop with others (e.g., camp counselors, staff, director). Typical responses for items they shared included songs, icebreakers, and games. Most respondents (94.7\%) also indicated they gained skills that they will be able to transfer to other areas of life besides camp (e.g., school, work). 
Table 7. Counselors' Belief About Whether Skills from Competency Sessions Were Used During the Camping Experience

\begin{tabular}{|l|c|}
\hline \multicolumn{1}{|c|}{ Competency } & $\%$ responding yes \\
\hline Teaching and facilitating $(n=19)$ & $89.4 \%$ \\
\hline Role model $(n=27)$ & $85.1 \%$ \\
\hline Understanding organizational and camp environment $(n=20)$ & $85.0 \%$ \\
\hline Communication $(n=19)$ & $84.2 \%$ \\
\hline Professionalism $(n=30)$ & $83.3 \%$ \\
\hline Supportive relationships $(n=30)$ & $83.3 \%$ \\
\hline Self-direction $(n=26)$ & $80.7 \%$ \\
\hline Professional development $(n=19)$ & $73.6 \%$ \\
\hline Cultural awareness $(n=30)$ & $73.3 \%$ \\
\hline Personal commitment $(n=32)$ & $68.7 \%$ \\
\hline Child and adolescent development knowledge $(n=27)$ & $62.9 \%$ \\
\hline Health, wellness, and risk management $(n=27)$ & $62.9 \%$ \\
\hline Note. $n$ is based $n$ ( $n$ ) & \\
\hline
\end{tabular}

Note. $n$ is based on the number of responses to the specific competency question. The percentage is related to the number of respondents who indicated camp counselor workshop participants improved their skills related to the competency.

\section{4-H Professionals}

All 4-H professionals reported that they believed their camp counselors gained skills to use in their county camping role. The skills used in their camping role that received the highest ratings were teaching and facilitating games/icebreakers, camp planning, leadership skills, and song leading. 4-H professionals also believed camp counselors gained skills related to competencies. Similar to the 4-H camp counselors, the program planning session, which is offered annually, is highly rated each year (overall percentage of yes responses was $74.69 \%$ with $N=63$ ). The competencies that 4-H professionals indicated were used the most were the teaching and 
Journal of Youth Development | http://jyd.pitt.edu/ | Vol. 16 Issue 1 DOI 10.5195/jyd.2021.970

State 4-H Camp Counselor Workshop

facilitating, self-direction, and role model competencies. Table 8 presents the findings on skills gained or improved by competency.

\section{Table 8. 4-H Professionals' Belief About Camp Counselor Skills Gained or Improved Related to Corresponding Competency}

\begin{tabular}{|c|c|}
\hline Competency & $\%$ indicating improvement \\
\hline Teaching and facilitating $(n=19)$ & $84.2 \%$ \\
\hline Self-direction $(n=27)$ & $74.0 \%$ \\
\hline Role model $(n=27)$ & $70.3 \%$ \\
\hline Supportive relationships $(n=17)$ & $58.8 \%$ \\
\hline Personal commitment $(n=17)$ & $52.9 \%$ \\
\hline Communication $(n=19)$ & $47.3 \%$ \\
\hline Professionalism $(n=17)$ & $41.1 \%$ \\
\hline Professional development $(n=19)$ & $36.8 \%$ \\
\hline Understanding organizational and camp environment $(n=19)$ & $36.8 \%$ \\
\hline Child and adolescent development $(n=27)$ & $22.2 \%$ \\
\hline Health, wellness, and risk management $(n=27)$ & $22.2 \%$ \\
\hline Cultural awareness $(n=17)$ & $11.7 \%$ \\
\hline Do not believe they gained or improved $(n=63)$ & $1.5 \%$ \\
\hline
\end{tabular}

Note. $n$ is based on the number of responses to the specific competency question. The percentage is related to the number of respondents who indicated camp counselor workshop participants improved their skills related to the competency.

In addition to competencies, $4-\mathrm{H}$ professionals reported that camp counselors gained some level of skill development related to leadership (98.5\% agreement), decision making (98.4\% agreement), and teamwork (97.1\% agreement). Table 9 presents the extent to which $4-\mathrm{H}$ professionals believed that camp counselors who attended the workshop gained skills. 


\section{State 4-H Camp Counselor Workshop}

Table 9. 4-H Professionals' Belief About Skills Gained or Improved by Camp Counselors Because They Attended MXC

\begin{tabular}{|l|c|c|c|c|c|}
\hline Skills & Not at all & $\begin{array}{c}\text { To a small } \\
\text { extent }\end{array}$ & $\begin{array}{c}\text { To a moderate } \\
\text { extent }\end{array}$ & $\begin{array}{c}\text { To a great } \\
\text { extent }\end{array}$ & N \\
\hline Teamwork & $2(2.8 \%)$ & $14(19.7 \%)$ & $37(52.1 \%)$ & $18(25.3 \%)$ & 71 \\
\hline Leadership & $1(1.4 \%)$ & $9(13.4 \%)$ & $36(53.7 \%)$ & $21(31.3 \%)$ & 67 \\
\hline Decision making & $1(1.5 \%)$ & $12(18.1 \%)$ & $40(60.6 \%)$ & $13(19.6 \%)$ & 66 \\
\hline
\end{tabular}

In addition to believing their camp counselors gained skills, the vast majority $(82.5 \%)$ of $4-\mathrm{H}$ professionals indicated that workshop participants shared an idea that they had learned from the workshop during the county camp counselor training process (e.g., songs, themes, team building, and particular programming efforts). When exploring workshop program indicators, 4-H professionals believed the main benefits of the workshop were for camp counselors to enhance skills $(50.0 \%)$ and share ideas (35.7\%). 4-H professionals indicated they were "very likely" (86.6\%) or "somewhat likely" $(6.6 \%)$ to send camp counselors to the workshop in future years.

\section{Discussion and Implications}

The purposes of the study were to assess (a) if camp counselors gained skills and knowledge from attending the MXC workshop; (b) whether or not they shared ideas from the workshop in their county-level camping program with peer camp counselors, adult camp staff, and/or 4-H professionals who serve as camp directors; and (c) if those skills and knowledge transferred to their role as a camp counselor in the county's summer camping program. The results demonstrate that first-year camp counselors attending the MXC workshop learned skills and knowledge, shared ideas, and transferred their skills and knowledge to their role as a summer camp counselor.

Both 4-H professionals and camp counselors indicated the main benefits of the workshop were enhancing skills and sharing ideas. Camp counselors and 4-H professionals indicated competencies were strengthened; highly rated competencies by both groups were program planning, teaching and facilitating, and role modeling. Strengthening competencies aligns with 


\section{State 4-H Camp Counselor Workshop}

previous research related to intentionally designing training to produce desired outcomes (Galloway et al., 2013; Gillard \& Roark, 2017).

There are a few reasons why the program planning competency was highly rated. The session focused on program planning is offered annually versus on a rotation. The camp counselor participants have an opportunity to practice this competency both at the workshop and then later in their own county camping program, so have multiple chances to enhance and transfer skills. Allowing opportunities for learners to develop their learning and their experience maximizes their learning (Femrite \& Flatt, 2017). Additionally, when camp counselor workshop participants implement the activity at the workshop, they are learning experientially (Kolb, 1984), which increases transfer of learning.

Teaching and facilitating and role modeling competencies were also highly rated. These competencies are used throughout their role as a camp counselor. When teens act as teachers, they report gaining skills related to teaching, including preparation and engaging with youth (Ripberger \& Blalock, 2013; Weybright et al., 2016). This may occur when leading a song, giving instructions for how to make a craft, or facilitating a game. Teen camp counselors have been identified as teachers and facilitators when helping campers learn specific skills and as role models whom campers looked up to (Wilson \& Sibthorp, 2018). Teen camp counselors recall what it was like when they were campers and looked up to their teen leaders, so they take their role of role modeling seriously (Bird \& Subramaniam, 2018).

In addition to strengthening competencies, findings from camp counselors indicate they believed they were a better camp counselor and gained skills to use in their camping experience. Many of the skills identified from open-ended comments were related to singing, icebreakers or games, and scenarios related to handling behavior management. These skills are noticeable to the camp counselors, and in turn likely easy to observe in a camp setting. For instance, a camp counselor leads a song they learned at the workshop with fellow camp counselors during their county training and then later leads campers in the song during camp. By taking the knowledge learned and applying it to the related role, transfer of learning occurs (Mayer, 2002). Perkins and Salomon (1992) describe two general strategies that foster this transfer-hugging and bridging-that are relevant to MXC. Hugging is "instruction [that] directly engage[s] learners in approximations to the performances desired" (p. 10). Bridging strategies activate past experiences and engage learners in reflecting about the strengths and weakness of a plan. Therefore, the active learning experiences such as those used in the MXC workshop sessions likely aided in learning transfer. Additionally, camp counselors indicated they gained 


\section{State 4-H Camp Counselor Workshop}

skills that they will be able to transfer to other areas besides camp (e.g., school, work), suggesting that the workshop environment is an experience to aid young people in gaining applied skills (Duerden et al., 2014).

Findings from 4-H professionals suggest that the camp counselors gained easily visible skills and also more abstract skills, including teaching and facilitating, teamwork, leadership, and decisionmaking skills by attending the workshop. More abstract skills (leadership skills, teamwork/cooperation, teaching methods) may be harder for counselors to identify because they may not observe themselves directly performing that skill, further demonstrating the importance of obtaining multiple perspectives (i.e., camp counselor participants and 4-H professionals). Other studies (e.g., Wilson \& Sibthorp, 2018) discuss finding support for skills gained but youths do not mention them during the data collection process.

The fact that camp counselors and professionals agree on skills gained, ideas shared, and transference of learning suggests that workshop attendance provides beneficial outcomes for the camp counselors' skill development. This is a benefit of having two perspectives of the workshop's impact.

\section{Limitations}

A few study limitations are acknowledged. One limitation is having duplicate 4- $\mathrm{H}$ professional respondents over the 3-year span of the study. Even though individuals were asked to respond on the experience in the current year, there is potential that they inadvertently considered previous workshops. 4-H professionals were also asked to respond for all participants as a group. If they had multiple camp counselors attend the workshop, they did not have an opportunity to differentiate between the camp counselors and the respective impact of the workshop. There is also potential for discrepancies in whether 4-H professionals were able to attribute camp counselors' competencies to their workshop attendance, given that camp counselors participate in additional training in their county. Despite these limitations, for the intent of our study, and consistent with prior literature, the findings still enabled us to establish tentative conclusions about the workshop's impacts.

\section{Implications for Practice and Future Directions}

The findings from this study have implications for strategies that may assist youth development professionals to develop and implement similar training workshops where the goal is transfer of learning. Specific recommendations include the following: 


\section{State 4-H Camp Counselor Workshop}

- Identify specific desired competencies or other skills and intentionally design training with such a focus.

- Allow for planning opportunities during the workshop to promote transfer of learning. Teach games, icebreakers, songs, and other programmatic activities with active learning strategies so participants can take these ideas back to their respective camping programs to share with others and then lead them at camp. These active learning strategies assist in the transfer of learning.

- Incorporate sessions that focus on enhancing skills such as dealing with situations that may arise at camp and idea sharing, as these elements were indicated as main benefits of the workshop. Evaluating the benefits of the workshop will guide the development of future programs.

- Offer the training to individuals who span diverse locations and experiences. Having a larger audience, such as a statewide one, provides an opportunity to meet new individuals and learn new ideas. It also allows for county- and state-based 4-H professionals to interact with youth throughout the state and share their own skill set with camp counselors beyond their county lines.

- Assess specific skills and competencies by using a retrospective post-then-pre format. Respondents would be able to consider their skills and competencies presently and prior to the workshop, which avoids pretest sensitivity and response-shift bias that result from pretest overestimation or underestimation (Klatt \& Taylor-Powell, 2005).

- Include questions to assess the skills that are more challenging to observe to enable participants to self-identify the skills they have gained (e.g., "I am able to plan games that better serve the age group I am working with" instead of "I gained skills related to the child and adolescent development knowledge competency").

Participating in the workshop benefitted teen camp counselor workshop participants as they enhanced their own skills, shared ideas, and transferred what they learned; in turn, when the skills they learned were put to use, their county's camp programming benefitted. Based on the camp counselor participants' and 4-H professionals' positive comments and high ratings, we believe we have found a format that works well in meeting camp counselor training needs. The workshop provides an opportunity for youth development professionals to bring practical, research-based, hands-on learning to life through a camp format in a statewide training. 
Journal of Youth Development | http://jyd.pitt.edu/ | Vol. 16 Issue 1 DOI 10.5195/jyd.2021.970

State 4-H Camp Counselor Workshop

\section{References}

Baldwin, J., Duerden, M. D., \& Witt, P. A. (n.d.). The impact of counselor training on new and returning camp counselors. Camping Magazine, American Camp Association.

https://www.acacamps.org/resource-library/articles/impact-counselor-training-new-returningcamp-counselors

Bell, B. S., \& Kozlowski, S. W. J. (2008). Active learning: Effects of core training design elements on selfregulatory processes, learning, and adaptability. Journal of Applied Psychology, 93(2), 296-316. https://doi.org/10.1037/0021-9010.93.2.296

Bird, M., \& Subramaniam, A. (2018). Teen staff perceptions of their development in camp: Insights for theory and practice. Journal of Youth Development, 13(1-2), 62-82. https://doi.org/10.5195/jyd.2018.568

Boone, H. N., \& Boone, D. A. (2012). Analyzing Likert data. Journal of Extension, 50(2), tt2. https://archives.joe.org/joe/2012april/tt2.php

Byham, W. C., \& Moyer, R. P. (2005). Using competencies to build a successful organization [Monograph]. https://onpointcoaching.typepad.com/files/using competancies to build org.pdf

Campion, M. A., Fink, A. A., Ruggeberg, B. J., Carr, L., Phillips, G. M., \& Odman, R. B. (2011). Doing competencies well: Best practices in competency modeling. Personnel Psychology, 64(1), 225-262. https://doi.org/10.1111/j.1744-6570.2010.01207.x

Cochran, G., \& Ferrari, T. M. (2009). Preparing youth for the 21st century knowledge economy: Youth programs and workforce preparation. Afterschool Matters, 8, 11-25.

Digby, J. K., \& Ferrari, T. M. (2007). Camp counseling and the development and transfer of workforce skills: The perspective of Ohio 4-H camp counselor alumni. Journal of Youth Development, 2(2), 103-122. https://doi.org/10.5195/JYD.2007.349

Duerden, M. D., Witt, P., Garst, B., Bialeschki, D., Schwarzlose, T., \& Norton, K. (2014). The impact of camp employment on the workforce development of emerging adults. Journal of Park and Recreation Administration, 32(1), 26-44.

Epley, H. K. (2014). Defining and describing Ohio 4-H camp counselor core competencies. (Unpublished doctoral dissertation). The Ohio State University. http://rave.ohiolink.edu/etdc/view?acc num=0su1398709972

Epley, H. K., Williams, J., Feldhues, K., \& Hall, L. (2018). Making extreme counselors: A state 4-H camp counselor workshop. Journal of Extension, 56(6), iw5. https://archives.joe.org/joe/2018october/iw5.php

Epley, H. K., Ferrari, T. M., \& Cochran, G. R. (2017). Development of a competency model for a state 4-H camp counselor program. Journal of Park and Recreation Administration, 35(2), 51-73. https://doi.org/10.18666/JPRA-2017-V35-I2-7211 
Journal of Youth Development | http://jyd.pitt.edu/ | Vol. 16 Issue 1 DOI 10.5195/jyd.2021.970

State 4-H Camp Counselor Workshop

Femrite, S., \& Flatt, J. (2017). Transformative leadership: The camp counselor experience. Journal of Youth Development, 11(3), 132-140. https://doi.org/10.5195/jyd.2016.466

Ferrari, T. M., \& Arnett, N. (2011). Implementing a work-based learning approach to 4-H camp counseling. Journal of Youth Development, 6(4), 3-17. https://doi.org/10.5195/jyd.2011.161

Ferrari, T. M., Arnett, N., \& Cochran, G. (2008). Preparing teens for success: Building $21^{\text {st }}$ century skills through a 4-H work-based learning program. Journal of Youth Development, 3(1), 1-25. https://doi.org/10.5195/jyd.2008.317

Ferrari, T. M., \& McNeely, N. N. (2007). Positive youth development: What's camp counseling got to do with it? Findings from a study of Ohio 4-H camp counselors. Journal of Extension, 45(2), rb7. https://archives.joe.org/joe/2007april/rb7.php

Ferrari, T. M., \& Risch, L. S. (2013). Exploring 4-H camp counseling as a context for developing responsibility. American Camp Association National Camp Research Symposium Abstracts. https://www.acacamps.org/sites/default/files/resource library/2013-National-Research-ForumBook-Abstracts.pdf

Galloway, R., Bourdeau, V., Arnold, M., \& Nott, B. D. (2013). Tying the design of your camp staff training to the delivery of desired youth outcomes. Journal of Extension, 51(4), iw3.

https://archives.joe.org/joe/2013auqust/iw3.php

Garst, B. A., Browne, L. P., \& Bialeschki, D. M. (2011). Youth development and the camp experience. New Directions for Youth Development, 2011(130), 73-87. https://doi.org/10.1002/yd.398

Garst, B. A., Gagnon, R. J., \& Whittington, A. (2016). A closer look at the camp experience: Examining relationships between life skills, elements of positive youth development, and antecedents of change among camp alumni. Journal of Outdoor Recreation, Education, and Leadership, 8(2), 180-199. https://doi.org/10.18666/JOREL-2016-V8-I2-7694

Garst, B., \& Johnson, J. (2005). Adolescent leadership skill development through residential 4-H camp counseling. Journal of Extension, 43(5), rb5. https://archives.joe.org/joe/2005october/rb5.php

Gillard, A., \& Roark, M. F. (2017). Does staff training on camper friendship skills make a difference to campers with serious illness? Journal of Park and Recreation Administration, 35(4), 1-12.

https://doi.org/10.18666/JPRA-2017-V35-I4-8004

Klatt, J., \& Tayor-Powell, E. (2005). Using the retrospective post-then-pre design (Quick Tips \#27). Program Development and Evaluation, University of Wisconsin-Extension. https://fyi.extension.wisc.edu/programdevelopment/files/2016/04/Tipsheet27.pdf

Klieme, E., Hartig, J., \& Rauch, D. (2008). The concept of competence in educational contexts. In J. Hartig, E. Kleime, \& D. Rauch (Eds.), Assessment of competencies in educational contexts (pp. 322). Hogrefe.

Kolb, D. A. (1984). Experiential learning: Experience as the source of learning and development. Prentice Hall. 
Journal of Youth Development | http://jyd.pitt.edu/ | Vol. 16 Issue 1 DOI 10.5195/jyd.2021.970 State 4-H Camp Counselor Workshop

Leff, D. M., Retallick, M. S., \& Franz, N. K. (2015). Transformative learning and the 4-H camp counselor experience in Minnesota. Journal of Human Sciences and Extension, 3(3), 1-17.

https://www.jhseonline.com/article/view/740/641

Mayer, R. E. (2002). Rote versus meaningful learning. Theory into Practice,41(4), 226-232. https://doi.org/10.1207/s15430421tip4104 4

McClelland, D. C. (1973). Testing for competence rather than for "intelligence." American Psychologist, 28(1), 1-14. https://doi.org/10.1037/h0034092

National 4-H Headquarters. (2011). Essential elements [Fact sheet]. https://nifa.usda.gov/sites/default/files/resource/Essential Elements.pdf

Nicholson, D. J., \& Klem, M. D. (n.d.). The value of being a camp counselor: A study of the experiences and personal growth of Missouri 4-H camp counselors. Camping Magazine, American Camp Association. https://www.acacamps.org/resource-library/camping-magazine/value-being-campcounselor-study-experiences-personal-growth-missouri-4\%E2\%80\%91h-camp-counselors

Perkins, D. N., \& Salomon, G. (1992). Transfer of learning. In T. Husen \& T. N. Postlethwaite (Eds.), International encyclopedia of education ( $2^{\text {nd }}$ ed., Vol. 11, pp. 6452-6457). Pergamon Press.

Ripberger, C., \& Blalock, L. (2013). Training teens to teach agricultural biotechnology: A National 4-H science demonstration project. Journal of Youth Development, 8(3), 46-67.

https://doi.org/10.5195/jyd.2013.84

Schunk, D. H. (2012). Learning theories: An educational perspective (6 $6^{\text {th }}$ ed.). Pearson.

Seale, C. (2010). Quality issues in qualitative inquiry. In P. Atkinson \& S. Delamont. (Eds.), SAGE qualitative research methods (pp. 98-109). SAGE Publications.

https://doi.org/10.4135/9780857028211

Silliman, B., Edwards, H. C., \& Johnson, J. C. (2020). Preparing capable youth workers: The project youth extension service approach. Journal of Youth Development, 15(1), 122-149.

https://doi.org/10.5195/jyd.2020.824

Wahl-Alexander, Z., Richards-Rosse, K. A., \& Howell, S. (2018). The influence of online training on camp counselor perceived competence. Journal of Park and Recreation Administration, 36(4), 72-89. https://doi.org/10.18666/JPRA-2018-V36-I4-8611

Weybright, E. H., Hrncirik, L. M., White, A. J., Cummins, M. M., Deen, M. K., \& Calodich, S. (2016). "I felt really respected and I know she felt respected too": Using youth-adult partnerships to promote positive youth development in 4-H youth. Journal of Human Sciences and Extension, 4(3), 93110.

Wilson, C., \& Sibthorp, J. (2018). Examining the role of summer camps in developing academic and workplace readiness. Journal of Youth Development, 13(1-2), 83-104.

https://doi.org/10.5195/jyd.2018.563 